\title{
Farmer satisfaction with policing in rural Victoria, Australia
}

\author{
Alistair Harkness \\ School of Arts \\ Federation University Australia \\ PO Box 3191 \\ Gippsland Mail Centre VIC 3841 \\ AUSTRALIA
}

and

Jo-ann Larkins

School of Science, Engineering and Information Technology

Federation University Australia

PO Box 3191

Gippsland Mail Centre VIC 3841

AUSTRALIA

Contact author - Alistair Harkness; alistair.harkness@federation.edu.au; +61 351226760

\begin{abstract}
Recognising that the impacts of acquisitive crime on farms are both economic and social, the Victorian Farm Crime Research Project is an ongoing endeavour to examine farm crime in Victoria. Specifically, the Project is considering attitudes of farmers and farming communities to criminal justice responses to farm crime; assessing existing policing practices and analysing alternatives; and determining a suite of strategies for prevention and control of crime against farms and for improvement of service delivery by the criminal justice system in Victoria. A quantitative survey of Victorian farmers was conducted between August 2017 and November 2018. This paper reports on and assesses results from the survey, providing results of parametric testing on a series of Likert scale questions which enable an analysis of farmer attitudes to rural policing, crime and victimisation. Overall farmers' attitudes to rural policing are generally positive. There is a perception, however, that the policing focus is not aligned with farming communities' priorities and that the police are under-resourced. Farmers who have been a victim of theft have less positive thoughts on police in the local area. People who are members of local community organisations have higher opinions of local police. It argues that there needs to be a synthesised campaign to build stronger relationships between police and farm communities, and that this can be achieved primarily through enhanced resourcing of local police in rural areas of Victoria and the resourcing of team of fulltime rural crime investigators.
\end{abstract}

Key words: farm crime, rural policing; perceptions of police; Australia 


\section{Introduction}

This article draws on results of a survey of farmers in Victoria, Australia, assessing their perceptions of crime and criminal justice and their attitudes to rural policing in their communities. This research reports, inter alia, that there is a significant reluctance for farmers to report crime, most commonly because of a belief that there is not enough evidence for police to proceed or that it may be difficult to tell if a crime has occurred; farmers are dissatisfied with various aspects of rural policing, most notably resourcing for local police; people involved in formal local organisations tend to have higher levels of satisfaction with police; and there is a stark lack of awareness of Victoria Police's Agricultural (Farm Crime) Liaison Officers.

What follows is a review of literature which focuses on rural policing, and findings from the survey are presented and discussed. On the basis of this research, we argue that there is a need for a synthesised campaign to systematically further build and strengthen partnerships between police and residents, and for enhanced resourcing of local police, recognising that a sizeable 'dark figure' of unreported crime exists in farming localities. This will lead to closer cooperation and improved public confidence in police and smarter, more focussed rural policing.

\section{Rural policing scholarship}

The imbalance between the study of crime in urban compared with rural and regional settings is well documented. The study of rural crime has been in the past "neglected" and "ignored" (Donnermeyer, 2007, pp. 2, 3; Jones, 2010, p. 37), "among the least studied phenomena in criminology" (Donnermeyer, Jobes \& Barclay (2006, p. 199), and "has received little attention in the research literature beyond occasional descriptive glances" (Weisheit \& Wells, 1996, p. 379; Harris \& Harkness, 2016, p. 1). Yet, as Donnermeyer (2016, p. 1) highlights in his introduction to The Routledge International Handbook of Criminology, "the field of rural criminology has grown from the status of being mostly unknown to one that is now beginning to inform the broader field of criminology", a development which has occurred over the past two decades.

There has hitherto been a distinct lack of attention to the study of rural crime and criminology in Australian texts (Scott et al, 2007, p. 1), and this remains so in both generalist criminology and criminal justice texts. Nevertheless, in addition to Barclay et al's (2007) Crime in Rural Australia, Hogg and Carrington's (2006) Policing the Rural Crisis and O'Connor and Gray's (1989) Crime in a rural Community - each pioneering works in an Australian context - there has been a recent emergence of further dedicated attention to rural criminology from Australia (Harkness, Harris \& Baker, 2016), Sweden (Ceccato, 2016) and internationally (Donnermeyer, 2016).

Although Donnermeyer and Barclay (2005, pp. 4-8) note that very little scholarly research had been conducted specifically on farm crime up to 2005, farm crime as a specific research focus is gaining traction. For example, a special edition of this journal in June 2017 (Volume 3, Issue 2) contained eight research articles considering issues around farm crime; in South Africa, Clack (2013) and Clack and Minnaar (2018) have studied livestock theft; and research emanating from Australia features prominently in the catalogue of available literature. Most notable are the contributions of Anderson and McCall (2005) who produced a monograph for the Australian Institute of Criminology with a focus on crime prevention; and 
the extensive works of Elaine Barclay over a sustained period of time focussing on both the theoretical and practical aspects of rural criminology and farm victimisation (see for example Barclay, 2003; Barclay \& Donnermeyer, 2007; Barclay 2016). In 2019, an edition of Acta Criminologica: Southern African Journal of Criminology (Volume 31, Issue 4) was published with 11 papers focused on various aspects of rural crime (including farm crime and poaching), a collection of research which contributes greatly to providing much needed additional focus on rural offending and its impacts.

Whilst the canon of scholarly works focussing on rural policing is a little more extensive, it remains limited. This is compounded by a tendency for rural communities to keep problems within the community, informal problem solving and mistrust of government (Muhammad, 2002, p 2). Bristow (1982) provided an assessment of the characteristics which influence styles and methods of rural policing in an American context, and Weisheit, Falcone and Well's (2006) analysis of rural crime and policing also in an American context, first published in 1996, is now in its third edition. O'Connor and Gray's (1989) research, based on extensive interviews and observation, examined victimisation, fear of crime and policing in Australia, in the rural New South Wales township of Walcha. Mawby and Yarwood's (2016) edited collection Rural Policing and Policing the Rural provides a comprehensive international consideration of an array of rural policing issues. However, Mawby (2004, p $431)$ notes that "[ $t]$ he nature of policing in rural areas has raised relatively little debate".

In Australia, there exists some recent state-based farm crime research (Barclay in New South Wales and Harkness in Victoria) but no national research since Anderson and McCall (2005). Hence, we are faced with an incomplete picture of the extent of farm crime or attitudes of farmers and police to rural police and policing contemporaneously. Australian farm crime research conducted previously incorporates a variety of methodologies, and much of the existing research is now dated. However, previous research indicates that victimisation is high amongst farmers and that the impacts of farm crime are heightened at certain times, such as amidst drought (Barclay et al, 2001; Barclay, 2003; Carcach, 2002; McCall \& Homel, 2003).

What is largely absent from contemporary considerations of farm crime and rural policing is a focus on attitudes, policy and practice in the State of Victoria (see, however, Harkness, 2015; 2016; 2017). The Victorian Farm Crime research project is an ongoing scholarly endeavour to examine a range of issues around farm crime in Victoria. Specifically, the project is considering attitudes of farmers and farming communities to criminal justice responses to farm crime; assessing existing policing practices and analysing alternatives; and determining a suite of strategies for prevention and control of crime against farms and for improvement of service delivery by the criminal justice system in Victoria.

\section{Features of rural communities and rural policing}

Perhaps the four greatest challenges for rural policing can be condensed to (i) geography and the tyranny of distance; (ii) rural stoicism and under-reporting of crime; (iii) familiarity between police and residents; and (iv) resources and rural-specific training.

(i) Rural areas in Australia are characterised by remoteness and larger distances between properties compared with capital and provincial cities, with populations that are smaller and less dense than urbanised settlements (Donnermeyer \& Barclay, 2005, p. 6). This allows, then, enhanced access to farms and rural properties via multiple entry and exit points. 
Combined with improved transport infrastructure and changing or unstable populations, lack of capable guardianship and opportunity allows for offending to occur (McCall \& Homel, 2003). Distance also means that travel times for police are increased, thus impacting on timeliness of response.

(ii) Victimisation against farmers is difficult to accurately measure, and underreporting leads to a 'dark figure of crime' - the term used to describe crimes committed but which are not recorded in the official statistics. Informal social control and a reticence to share internal problems can affect rates of crime reporting and recording (Donnermeyer, 1995) and it can also be difficult to strictly classify crime as either rural or urban (Carcach, 2000). Studies in New South Wales in 2001 (Barclay et al, 2001) and New South Wales and Queensland in 2014 (Barclay, 2015) showed (on both occasions) that only half the crime experienced on farms was reported, oftentimes because of perceptions of police ineffectiveness (Barclay, 2003). There are several consequences of non-reporting: police are unable to investigate crimes which are occurring; offenders continue to offend, leading to further victimisation; and there are policy and decision making implications when an accurate understanding of the true extent of rural offending rates and patterns is not produced and resources are therefore not appropriately allocated (Harkness, 2018).

(iii) There is scant anonymity for police working in smaller rural locations where they know their families interact with others at schools, churches and other gathering places (Anderson \& McCall, 2005, p. 31). Rural police often work in isolation and are on call 24 hours a day (Bristow, 1982), and there exists, too, an ethical dilemma for rural police - to solve crimes in the rural community while simultaneously keeping the peace. Weisheit et al (1999) note that residents in rural areas are more likely to view officers as members of the local community first and as police officers second, acting as law enforcer but also being a local resident present in the community (Buttle, Fowler \& Williams, 2010). This, Donnermeyer and Barclay $(2005$, p. 6) argue, creates a sense of "social isolation of the rural police in the local community" with rural officers considered more like social workers (Marenin \& Copus, 1991).

For police in rural areas to be informed and effective, a strong working relationship must be maintained, and this requires the careful exercising of discretion (Jobes et al, 2000 cited in Donnermeyer \& Barclay, 2005, p. 7). In essence, police are part of the local community where they reside "and where, conversely, local people cooperate with the policing enterprise" (Mawby, 2004, p. 431). Jobes' (2003, p. 15) study of police officers in New South Wales found that a significant difficulty for rural police was the strain between the dual roles of law enforcer and local resident; rural police need to attend to a wide diversity of matters integrating and adapting to a local community; and in effect serving as a "good Samaritan" (Scott \& Jobes, 2007, p. 131).

(iv) There are only few instances where police jurisdictions will be entirely rural: in the vast bulk of localities, there will be a mix of town and rural-oriented policing duties. As such, the rural police officer must deal with a diversity of crimes. Anderson and McCall (2003, p. 36) note that they experience heavy workloads, lack of training and family pressures, and Weisheit et al (1994) observe that rural law enforcement officers must service their communities with lower budgets, less staff, and less equipment. In Barclay's (2003, p. 141) study of farm crime reporting, 23 percent of farm crime victims indicated that the lack of knowledge or understanding of farming by police was a reason for non-reporting. A paucity of education and training specifically for rural issues creates a knowledge deficit of 
police officers with rural specific crimes, culminating in lack of reporting when farmers believe that police have no knowledge or comprehension about farming.

These four key features of rural communities and rural policing impact on the style of policing best adopted in rural communities. There exists a symbiotic relationship between rural police and their own local community, and remembering Sir Robert Peel's principle that 'the police are the public and that the public are the police', a community-focussed policing style based on a partnership approach and the formation of collaborative relationships is not only desirable but also essential.

Anderson and McCall (2005, p. 37) note that rural policing in the latter part of the twentieth century changed from being proactive to "crisis driven and reactive" and with far less engagement. For example, they suggest that members of the public are now less likely to visit a police station for drivers' license requirements, and police less likely to visit farms where they would once have taken the opportunity to engage in an educative process around crime prevention. This, they argue, has been accentuated by an unwillingness of some officers to work in the bush.

Jobes' (2002, p. 256) study of attitudes of rural police in New South Wales found that "[r]ural officers were oriented toward practical community policing by being sensitive to expectations their communities have about providing service and maintaining order in addition to enforcing the law". Being accommodating to the community, an ability to listen and considering their role as a 24 hour a day job were also identified as being essential traits (Jobes, 2002). Jobes (2003b, p. 3) also notes that only after a police officer is integrated into a community can effective policing occur. Accountability and connectedness with community is necessary (Weisheit et al., 1999) and there exist few alternatives to community policing oriented practice (Sims, 1988 cited in Jobes, 2003, p. 4).

\section{Trust and confidence in police}

Ensuring trust and confidence in police is vital, leading to greater citizen participation in setting priorities, more locally accountable and responsive public bodies, enhanced cooperation with police and compliance with the law (Jackson and Bradford, 2010, p. 241) Goldsmith (2010, p. 444) argues that "police effectiveness and legitimacy of police actions" can be enhanced by public trust, noting though that "[ $t]$ rust is fragile due to its highly contingent character in most social relations".

Central to this current study is the degree to which farmers have trust and confidence in the police who serve their local communities. This is an international issue, even though rural perceptions of policing have not been extensively researched. Holmes et al (2017) note that very little research has been conducted on citizens' attitudes about policing in rural communities in the United States. Some primary data collection has occurred in an Australian context on attitudes to crime and policing specifically from the perspective of farmers, notably Barclay (2001 and 2014) in New South Wales and Queensland, and a national survey in 2000 (Anderson and McCall, 2005), although Victoria has not hitherto attracted attention.

In the United Kingdom, Mawby's (2004) study in Cornwell found that the inaccessibility of police in rural locales was a particular concern for rural residents, with a preference expressed for access to police at a local level rather than through centralised means. There is also a desire for more visible policing: Bradford et al. (2009, p. 20) argue 
that "[s]eeing regular police patrols and feeling informed about police activities are associated with higher opinions of effectiveness and community engagement". A lack of satisfaction with rural policing in the United Kingdom persists. A rural crime survey was conducted in the United Kingdom in 2018 (National Rural Crime Network, 2018, p. 4) and, in her foreword to the report on findings, the Chair of the National Rural Crime Network summarised the findings thus: "Crime is up. Anger is up. Frustration is up. Trust is down. Those rating the police as good is down". The survey found that perceptions of policing in rural communities is poor and significantly worse than in urban communities, also finding that satisfaction with local policing had reduced from a similar study conducted in 2015.

In an Australian context, Anderson and McCall (2005, pp. 33-34) outline five key themes around farmers' perceptions of policing: first, that police lack necessary resources; second, farmers felt as though they were under suspicion or at fault; third, farmers felt as though police lacked care about farm crime; fourth, farmers were of the belief that police lacked requisite knowledge or understanding about livestock investigation; and fifth, farmers are suspicious about some police and issues around familiarity between police and members of a rural community.

\section{Context of current study}

The State of Victoria is located in the south-east of the Australian mainland (see Figure 1) and at the August 2016 Census had a population of approximately six million persons. Approximately a quarter (24.2\%) of Victoria's population live outside of Greater Melbourne in regional and rural Victoria. The age profile is skewed higher in nonmetropolitan Melbourne with 40 percent of residents aged over 50 compared with 30 percent in Greater Melbourne (ABS, 2017), and a median age of 43 compared with 36 in Greater Melbourne (ABS Quickstats for Census, 2016).

\section{Figure 1: Broad land use in Victoria and Victoria in context ${ }^{1}$}

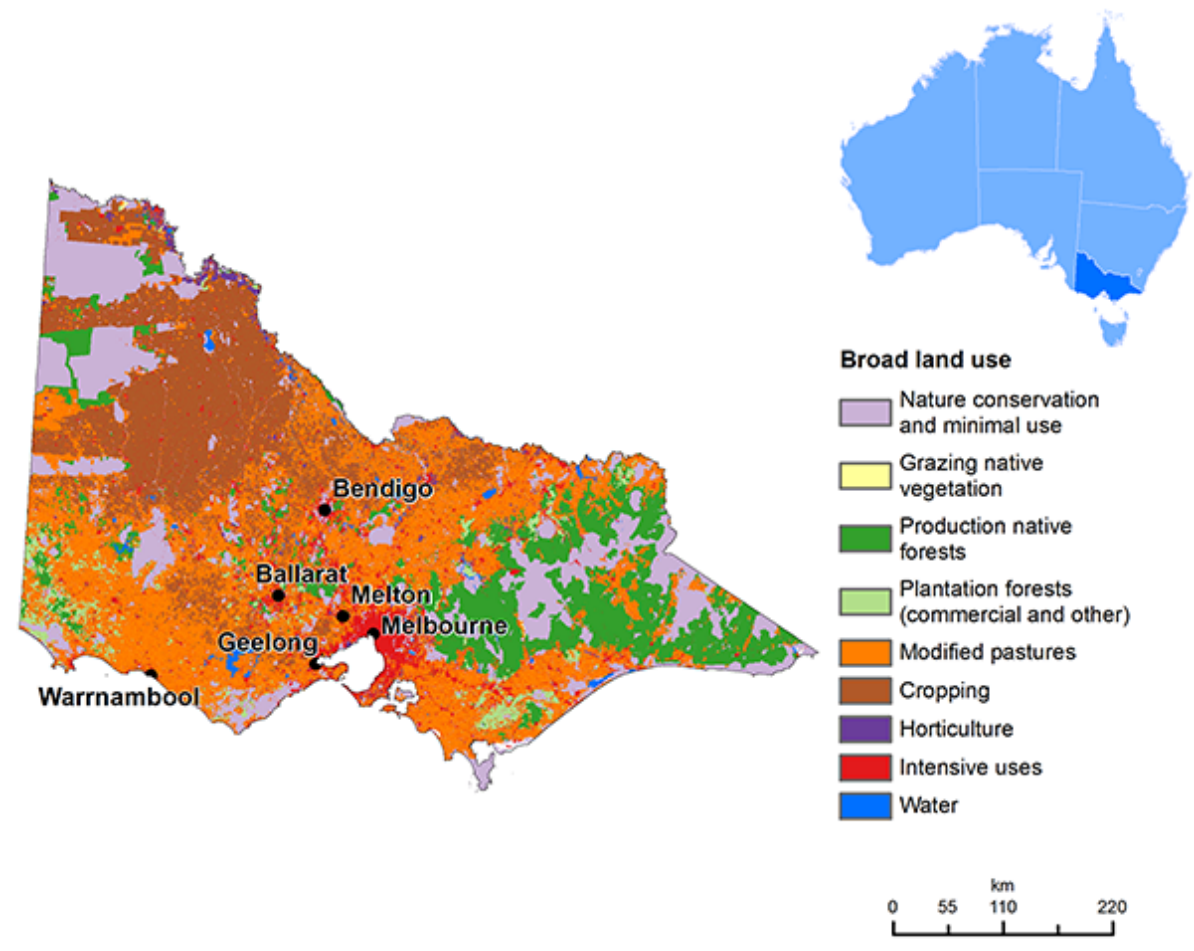


Across Australia, 250,700 people are employed in agriculture with approximately 85,000 farming business. The value of agricultural exports was $\$ 49$ billion in 2016-17; 70 percent of agricultural production is exported; and agriculture contributed three present to the nation's Gross Domestic product (ABARES, 2018). Victoria contributes 23 percent of Australia's total gross value of agricultural production (\$AUD14 billion of \$AUD61 billion in 2016-17). Milk (\$AUD2.2 billion), cattle and calves (\$AUD1.8 billion) and sheep and lambs (\$AUD1.5 billion) are the most significant agricultural commodities in Victoria, combined contributing 40 percent of Victoria's total value of agricultural production (ABARES, 2018). In 2015-16, there were 20,532 farms in Victoria with an estimated value of agricultural operations of \$AUD40,000 or more, and Victoria has 24 per cent of all farm businesses in Australia. The largest number of farms are primarily producing dairy and beef (ABARES, 2018). There are 29,661 agricultural businesses in Victoria employing about 91,000 people (Agriculture Victoria, 2018).

\section{Policing in rural Victoria}

In the context of Victoria, Australia, Robert Haldane (1995) provides a rich and colourful historical account of the emergence and growth of Victoria Police from a collection of disparate policing agencies, beginning in 1836. These autonomous forces included, by 1850 , the Rural Bench Constabulary made up of constables assigned to rural areas outside Police Magistrates' Districts (Public Records Office Victoria, 2016), prior to the formation of the Victoria Police Force in 1853 (Haldane, 1995, p. 5). Baker $(2005 ; 2014)$ has contributed significantly to our understandings of policing of conflict and industrial disputes, including in rural and regional contexts (Baker, 2016).

As of March 2019, Victoria Police employs 14,577 fulltime equivalent operational police (Victoria Police, 2019). A feature of rural policing in the State is the existence of Agricultural Liaison Officers (AGLOs) introduced in 2011 to provide expert advice regarding far crime, conduct investigations and maintain relationships with communities. They were renamed as Farm Crime Liaison Officers (FCLOs) in September 2019. FCLOs are general duties detectives and uniformed officers located at rural and regional police stations, most of whom have pre-existing farm experience, a farming background, qualifications, or a general interest in farming. They are not full-time rural investigators, and must juggle this responsibility with other duties (see Harkness, 2015). In addition to typically rural locations, FCLOs are also positioned at peri-urban and urban stations such as Geelong, Torquay and Frankston. There are more than 70 FCLOs across the state. The Victorian FCLO program relies on police volunteering their expertise and interest. This contrasts with New South Wales where a team of dedicated rural crime investigators are located strategically across the State (see NSW Police, 2019).

\section{Methodology}

A quantitative survey instrument was developed to collect data for this study $(n=906)$. Consisting of 47 mostly closed-ended questions, responses were collected between August 2017 and December 2018. Initially the survey was provided only as an online survey, publicised to Victorian farmers via Twitter posts and then on four occasions promoted to members of the Victorian Farmers Federation (VFF) with a link attached to a weekly news update. 
Receipt of online responses was slow, and anecdotally farmers indicated a reticence to respond to online surveys owing to the volume of emails received, and that emails associated with the running of the farm always take priority. In order to improve response rates, a four page survey containing the same questions was prepared and distributed in hardcopy form to approximately 6000 members of the VFF as an enveloped inclusion with the organisation's annual magazine in August 2018. Included with the survey was a plain language information statement and a reply-paid envelope. Hardcopy responses were also collected at two farm security events (August 2017 and June 2018), two gatherings of farmers (September 2017 and October 2017) and at an agricultural show (April 2018).

We acknowledge the fixed limitations of the survey data collected. The bulk of respondents are members of the VFF owing to this being the major pathway for participant recruitment. The survey was voluntary and so has a non-response bias and is skewed towards older participants with the time available to respond.

In addition to collecting some demographic data (including gender, age, postcode), the survey sought responses to questions pertaining to experiences of crime, perceptions of crime and criminal justice, reporting of crime, thoughts on police in the area where a respondents' farm is located, and on crime prevention behaviours. The survey was designed to take respondents approximately eight to ten minutes to complete. SPSS software has been used to analyse the data. Table 1 provides some selected demographic data. Almost three quarters of respondents were male; respondents were skewed toward older farmers with 69.53 percent aged over 55 years. Over four fifths of respondents operate full time farming businesses.

Table 1: Respondent demographics

Characteristics

Gender ( $\mathrm{n}=906)$

Female

Age $(\mathrm{n}=906)$

18-24 years

25-34 years

$35-44$ years

$45-54$ years

$55-64$ years

65-74 years

Over 75 years
Percentage

71.08

28.92

0.66

3.20

8.72

17.88

29.91

26.93

12.69

4.42

11.89

81.88

1.81 


\section{Results $^{2}$}

\section{Victimisation}

Of the total sample of 906 respondents, 68.14 percent indicated that they had been a victim of farm theft $(n=601)$ whilst 31.86 had not $(n=281)$. More than half of respondents had been the victim of farm theft over the preceding three years $(51.39 \%)$ and 27.42 percent has been a victim of theft within the preceding 12 months (refer to Table 2). This compares with the findings of Anderson and McCall $(2005$, p. 8) who reported the prevalence of crime in their survey period (2000-2001) at 27 percent.

Table 2: Recency of farm theft victimisation

When did the most recent theft from your farm occur $(n=609) \quad$ Percentage

Within the last 6 months $(\mathrm{n}=91)$

Between 6 and 12 months ago $(n=76)$

$1-3$ years ago $(\mathrm{n}=146)$

3-5 years ago $(n=106)$

More than 5 years ago $(n=190)$
12.48

23.97

17.41

Slightly over 79 percent of farm theft victims $(n=484)$ responded that they had reported the theft to police. 90.23 percent $(n=535)$ of these victims indicated that the stolen item(s) were not recovered.

\section{Thoughts on police in local area}

Survey participants were provided with eight prompts regarding aspects of policing in their local area and asked to indicate their level of agreement (for the first seven prompts) or satisfaction (for the eighth prompt), and these prompts along with percentage responses are provided in Table 3 . The dominant response is highlighted in bold.

In general, for each prompt more people "agreed" with the propositions. Notable exceptions were "I am satisfied that enough is being done by Victoria Police to prevent crime in my area" with 42.5 percent of respondents having a neutral opinion and "Local police are well resourced", with 38.30 percent neither agreeing nor disagreeing.

When comparing levels of agreement and disagreement for these two questions, more people disagreed than agreed with "Local police are well resourced" (42.1\% disagreed or strongly disagreed) and "I am satisfied that enough is being done by Victoria Police to prevent crime in my area (39.4\% disagreed or strongly disagreed). 
Table 3: Agreement/satisfaction with eight prompts regarding police in a respondent's local area

\begin{tabular}{|c|c|c|c|c|c|}
\hline Thoughts & $\begin{array}{c}\text { Strongly } \\
\text { agree }\end{array}$ & Agree & $\begin{array}{l}\text { Neither } \\
\text { agree nor } \\
\text { disagree }\end{array}$ & Disagree & $\begin{array}{l}\text { Strongly } \\
\text { disagree }\end{array}$ \\
\hline $\begin{array}{l}\text { The police in this area are } \\
\text { dealing with the things } \\
\text { that matter to people in } \\
\text { this community }(\mathrm{n}=880)\end{array}$ & $9.5 \%$ & $55.0 \%$ & $27.4 \%$ & $6.3 \%$ & $1.8 \%$ \\
\hline $\begin{array}{l}\text { The police in my area can } \\
\text { be relied on to be there } \\
\text { when you need them } \\
(n=883)\end{array}$ & $8.8 \%$ & $45.0 \%$ & $28.9 \%$ & $14.5 \%$ & $2.8 \%$ \\
\hline $\begin{array}{l}\text { The police in this area } \\
\text { treat everyone fairly } \\
\text { regardless of who they are } \\
(\mathrm{n}=881)\end{array}$ & $8.4 \%$ & $53.0 \%$ & $33.5 \%$ & $4.0 \%$ & $1.1 \%$ \\
\hline $\begin{array}{l}\text { I am satisfied that enough } \\
\text { is being done by Victoria } \\
\text { Police to prevent crime in } \\
\text { my area }(n=876)\end{array}$ & $2.6 \%$ & $25.6 \%$ & $42.5 \%$ & $24.0 \%$ & $5.4 \%$ \\
\hline $\begin{array}{l}\text { Local police are well } \\
\text { resourced }(\mathrm{n}=883)\end{array}$ & $2.6 \%$ & $17.1 \%$ & $38.3 \%$ & $33.0 \%$ & $9.1 \%$ \\
\hline $\begin{array}{l}\text { My local police are } \\
\text { accessible when I need } \\
\text { them }(n=885)\end{array}$ & $5.1 \%$ & $39.0 \%$ & $27.3 \%$ & $23.8 \%$ & $4.7 \%$ \\
\hline $\begin{array}{l}\text { I have a high level of trust } \\
\text { in police to deal with farm } \\
\text { crime }(n=879)\end{array}$ & $6.4 \%$ & $36.7 \%$ & $35.8 \%$ & $16.3 \%$ & $4.8 \%$ \\
\hline $\begin{array}{l}\text { Overall, how satisfied are } \\
\text { you with the standard of } \\
\text { policing in your local } \\
\text { area? }(\mathrm{n}=878)\end{array}$ & $6.5 \%$ & $47.2 \%$ & $30.5 \%$ & $13.1 \%$ & $2.7 \%$ \\
\hline
\end{tabular}




\section{Farm theft victimisation and thoughts on local police}

In order to determine the effect of farm crime victimisation on attitudes to police, the responses to the eight prompts provided in Table 3 were compared based on the responses to the question "Have you ever been a victim of theft from your farm?".

For all eight statements relating to thoughts on police in the local area, farmers who have not been a victim of theft had a better opinion of police. People who have been a victim had a poorer opinion of police. The farmers who "neither agree nor disagree" were mixed regarding whether they have been a victim. Our finding here, then is that farmers who have been a victim of theft have less positive thoughts about their local police.

The overall sum of the opinions of police is compared with "have you or someone on your farm ever been a victim of crime or offence" and is provided in Table 4 (note: a lower number equates to a better opinion of police). This confirms the finding that people who have been a victim of farm theft had a poorer opinion of police.

Table 4: Farm crime victimisation compared with overall thoughts of police

\section{Overall Thoughts Of Police}

Mean score

Have you ever been a victim of Yes theft from your farm?

\section{Belonging to organisation}

Illustrated in Table 5 is a comparison between membership of local civic organisations (respondents were provided with a list from which to choose) and their satisfaction with the standard of policing in their local area. Results are coloured coded from green (highest percentage), through orange (middle category) to red (lowest percentage).

Respondents who indicated that they were "not involved with any formal community organisation" had a lower amount of satisfaction with the police as well as a higher amount of dissatisfaction. Overall people who belong to community groups were more likely to say they were satisfied with local law enforcement. 
Table 5: Membership of local civic organisations compared with satisfaction with local policing

Overall, how satisfied are you with the standard of policing in your local area?

\begin{tabular}{|c|c|c|c|c|c|}
\hline & $\begin{array}{c}\text { Highly } \\
\text { satisfied } \\
\text { Row N \% }\end{array}$ & $\begin{array}{l}\text { Satisfied } \\
\text { Row N \% }\end{array}$ & $\begin{array}{c}\text { Neither } \\
\text { satisfied nor } \\
\text { dissatisfied } \\
\text { Row N \% }\end{array}$ & $\begin{array}{c}\text { Dissatisfied } \\
\text { Row N \% }\end{array}$ & $\begin{array}{c}\text { Highly } \\
\text { Dissatisfied } \\
\text { Row N \% }\end{array}$ \\
\hline $\begin{array}{l}\text { Neighbourhood } \\
\text { Watch }\end{array}$ & $10.3 \%$ & $48.7 \%$ & $33.3 \%$ & $7.7 \%$ & $0.0 \%$ \\
\hline $\begin{array}{l}\text { Country Fire } \\
\text { Authority }\end{array}$ & $6.6 \%$ & $49.1 \%$ & $29.2 \%$ & $13.2 \%$ & $2.0 \%$ \\
\hline $\begin{array}{l}\text { State Emergency } \\
\text { Service }\end{array}$ & $0.0 \%$ & $41.7 \%$ & $33.3 \%$ & $25.0 \%$ & $0.0 \%$ \\
\hline $\begin{array}{l}\text { Service } \\
\text { organisation (e.g. } \\
\text { Rotary, Lions, } \\
\text { Apex etc) }\end{array}$ & $7.7 \%$ & $56.4 \%$ & $25.6 \%$ & $9.0 \%$ & $1.3 \%$ \\
\hline $\begin{array}{l}\text { A local sporting } \\
\text { club }\end{array}$ & $6.4 \%$ & $47.2 \%$ & $31.0 \%$ & $13.8 \%$ & $1.5 \%$ \\
\hline $\begin{array}{l}\text { A local } \\
\text { community group }\end{array}$ & $5.9 \%$ & $49.9 \%$ & $28.2 \%$ & $13.5 \%$ & $2.6 \%$ \\
\hline $\begin{array}{l}\text { A kinder school } \\
\text { committee / } \\
\text { council }\end{array}$ & $10.7 \%$ & $48.2 \%$ & $23.2 \%$ & $14.3 \%$ & $3.6 \%$ \\
\hline $\begin{array}{l}\text { A senior citizens } \\
\text { group }\end{array}$ & $0.0 \%$ & $76.0 \%$ & $24.0 \%$ & $0.0 \%$ & $0.0 \%$ \\
\hline $\begin{array}{l}\text { Not involved with } \\
\text { any formal } \\
\text { community } \\
\text { organisation }\end{array}$ & $4.2 \%$ & $39.2 \%$ & $39.9 \%$ & $10.5 \%$ & $6.3 \%$ \\
\hline
\end{tabular}

To explore this further, the sum of police opinions was compared with membership of local organisations, and the results are shown in Table 6 . Note that a smaller number indicates greater satisfaction with the police, and that red equates to high and green to low values. People that were not involved with any community groups had a lower satisfaction with policing). People who had more satisfaction with police belong to Neighbourhood Watch and/or a senior citizens group.

Table 6: Overall thoughts of local police with local civic organisation membership

Overall Thoughts Of Police

Mean

Neighbourhood Watch

19.46 
Farmer satisfaction with policing in rural Victoria, Australia - Harkness and Larkins

Country Fire Authority

State Emergency Service

Service organisation (e.g. Rotary, Lions, Apex etc)

A local sporting club

A local community group

A kinder school committee / council

A senior citizens group

18.63

Not involved with any formal community organisation

22.96

\section{Satisfaction following an encounter with a Victoria Police officer}

Nearly 28 percent of respondents $(n=244)$ indicated that they had had an encounter with a member if Victoria Police in the preceding six months $(72.05 \% ; n=629$ had not). Of those that had had an encounter, 57.08 percent $(n=137)$ were highly satisfied or satisfied; 28.33 percent were neither satisfied nor dissatisfied $(n=68)$; and 14.58 percent were dissatisfied or highly dissatisfied $(n=35)$.

Table 7 compares levels of satisfaction with police with recent encounters with police. People who had a recent encounter with police were less satisfied with overall standard of policing in the area. For the people who had a recent encounter, 43.2 percent said they were "satisfied" with policing in the area. This compares with 49.3 percent of people who did not have a recent encounter with a police officer. Of those who had a recent encounter with police, 5.0 percent were highly dissatisfied with the standard of policing in the area; this compares with 1.9 percent who did not have a recent encounter with police. 
Table 7: Satisfaction with standard of policing compared with encounter with police

\begin{tabular}{|c|c|c|c|c|c|c|}
\hline & & \multicolumn{5}{|c|}{$\begin{array}{l}\text { Overall, how satisfied are you with the standard of policing } \\
\text { in your local area? }\end{array}$} \\
\hline & & $\begin{array}{c}\text { Highly } \\
\text { satisfied } \\
\text { Row N \% }\end{array}$ & $\begin{array}{l}\text { Satisfied } \\
\text { Row N \% }\end{array}$ & $\begin{array}{c}\text { Neither } \\
\text { satisfied } \\
\text { nor } \\
\text { dissatisfied } \\
\text { Row N \% }\end{array}$ & $\begin{array}{c}\text { Dissatisfied } \\
\text { Row N \% }\end{array}$ & $\begin{array}{c}\text { Highly } \\
\text { Dissatisfied } \\
\text { Row N \% }\end{array}$ \\
\hline $\begin{array}{l}\text { Have you had } \\
\text { any recent } \\
\text { encounter }\end{array}$ & Yes & $8.3 \%$ & $43.2 \%$ & $27.0 \%$ & $16.6 \%$ & $5.0 \%$ \\
\hline $\begin{array}{l}\text { with a } \\
\text { Victoria } \\
\text { police officer } \\
\text { in the last six } \\
\text { months? }\end{array}$ & No & $5.6 \%$ & $49.3 \%$ & $31.9 \%$ & $11.3 \%$ & $1.9 \%$ \\
\hline
\end{tabular}

\section{Reporting crime to police}

Previous research, most notably that of Barclay $(2003 ; 2015 ; 2016)$ in an Australian context, reveals that much farm crime goes unreported. To determine the extent of reporting in Victoria, respondents were asked to indicate how often they would report a theft from their farm to police. The majority $(67.5 \%, \mathrm{n}=591)$ would report any theft from their property "All of the time". 14.73 percent ( $n=129)$ would report "quite often"; 15.07 percent $(n=132)$ "occasionally"; and 2.74 percent $(n=24)$ "never". Using the overall sum of police opinions, the thoughts of police with "I would report any theft from my farm to the police" are compared and shown in Table 8. People who would report theft "All of the time" have a better opinion of police.

Table 8: Reporting of farm thefts with overall thoughts of police

\begin{tabular}{llc}
\hline & & $\begin{array}{c}\text { Overall Thoughts Of Police } \\
\text { Mean }\end{array}$ \\
\hline $\begin{array}{l}\text { I would report any theft from my } \\
\text { farm to the police. }\end{array}$ & All of the time & 21.35 \\
\cline { 2 - 3 } & Quite often & 21.77 \\
\cline { 2 - 3 } & Occasionally & 24.09 \\
\cline { 2 - 3 } & Never & 22.55 \\
\hline
\end{tabular}

Respondents were asked to nominate from a list provided the reason or reasons why they might be reluctant to report any theft from their farm to police (refer to Table 9). The most common for reluctance in reporting theft from farm is "A belief there is not enough evidence for police to proceed" and that "It may be difficult to tell if a crime has occurred". Using the overall sum of police opinions, the thoughts of police are compared with the nine reasons provided for reluctance in reporting a theft from a farm. The reason that " $A$ belief 
Farmer satisfaction with policing in rural Victoria, Australia - Harkness and Larkins

police would do nothing about it" was associated with less satisfaction/opinions of police. The reason "resolved issue without police" have higher satisfaction/opinions of police.

Table 9: Reasons for not reporting compared with mean thoughts of police

Overall Thoughts Of Police

\begin{tabular}{lcc} 
& $\mathrm{N}$ & Mean \\
\hline & & \\
It may be difficult to tell if a crime has occurred & 374 & 21.75 \\
A belief that it is not serious enough to report & 250 & 21.21 \\
If I do not hold insurance & 23 & 22.87 \\
Cost of loss is less than the insurance excess & 161 & 21.53 \\
A belief there is not enough evidence for police to proceed & 399 & 21.51 \\
A belief police would do nothing about it & 304 & 25.29 \\
If I have resolved the issue without police & 61 & 20.66 \\
Perpetrator known to me & 64 & 22.46 \\
Fear of revenge or retaliation by offender & 160 & 23.14 \\
\hline
\end{tabular}

Victoria's Agricultural (Farm Crime) Liaison Officers ${ }^{3}$

Asked "Are you aware that Victoria Police have Agricultural Liaison Officers (AGLOs) to provide assistance and advice to farm crime victims, and to investigate farm crime?", 67.0 percent of farmers responded that they were not. Awareness of AGLOs was compared with the mean of thoughts of police (Table 10). People who were aware of AGLOs had a slightly better opinion/thoughts on police.

Table 10: Awareness of AGLOs compared with mean of overall thoughts of police

Overall Thoughts Of

Police

Mean

\begin{tabular}{lll} 
Are you aware that Victoria Police have Agricultural & Yes & 21.35 \\
\cline { 2 - 3 } $\begin{array}{l}\text { Liaison Officers (AGLOs) to provide assistance and advice } \\
\text { to farm crime victims, and to investigate farm crime? }\end{array}$ & No & 22.10
\end{tabular}

\section{Summary and discussion}

In rural settings, a significant proportion of farms in Australia experience crime (Barclay et al., 2001; Carcach, 2002), and farm victimisation can impact 'the entire rural community and the wider agricultural industry' (McCall \& Homel, 2003, p 1). In addition to direct financial costs to the Australian economy, productive farmers leave the sector as a consequence of victimisation, and there are other financial and social costs throughout the agricultural sector (Anderson \& McCall, 2005, p. ix) 
Misplaced beliefs around rural offending exist because not all victimisation is reported, and non-reporting affects resourcing decisions for police. Because levels of trust and satisfaction with police influence reporting behaviour, there is an opportunity in Victoria for improvements in the relationships between the police and the policed though partnership building and a "soft policing" approach, which Wooff (2016) defines as "the non-coercive elements of policing", such as "community engagement, situated knowledge and negotiated order maintenance". Partnerships can extend, too, beyond just that between farmers and police, and can include strengthened - and formalised - partnerships with organised community organisations, rural insurers, local government bodies and other policing and crime prevention bodies. The central aim here, then, is to engage and to foster close cooperation, which leads to increased visibility, enhanced community connectedness, and closer cooperation between all parties.

Farmers who have been a victim of farm theft had a poorer opinion of police, a circumstance contributed to by the very low item recovery rate. For example, when livestock are stolen and processed quickly - such as by neighbours for their freezer or though illegal abattoirs - and combined with issues around evidence collection and the time taken to observe that a theft has occurred, there is little chance of an investigation leading to the successful return of the stock, or indeed for a prosecution. Oftentimes, farmers will recognise this reality and simply seek closure or an assurance that anything that could be done was in fact done by police. There is value, then, notwithstanding the additional time required to be committed, for post-investigation follow-up and provision of an explanation to assuage victims' feelings of dissatisfaction.

There is a role, too, for government and police command to improve levels of satisfaction, importantly in recognising that farm crime victimisation is a reality that harms local rural communities socially, emotionally and financially; and also impacts on the broader agricultural sector and therefore the national economy. Farm crime warrants far greater attention and resourcing to enable rural police to tackle farm crime effectively. Additional resourcing might include, for instance, enhanced training for general duties police working in regional and rural areas, and improvements to the provision of essential investigative tools, such as fit for purpose vehicles.

Notwithstanding the good work undertaken by rural police and the presence of AGLOs (FCLOs) since 2011, there appears to be a significant lack of awareness of their existence. Additional resourcing to bolster the FCLO program to create a dedicated rural crime investigator team would be highly desirable. A well-resourced, dedicated rural crime team - developing partnerships, engaging in community policing practices and fully investigating farm crime without distraction - we predict will lead to an uptake in reporting rates, improvements in satisfaction with local police, and a significant deterrent to offenders (and will be the focus of further comparative work between Victoria and New South Wales to produce empirical data).

The importance of active, engaged citizens cannot be under-estimated and support for local community organisations will allow their membership to be solidified and to expand. Those farmers who are members of Neighbourhood Watch are particularly satisfied with their local police, perhaps by virtue of being involved in a crime and safety oriented organisation). Similarly, members of senior citizens' groups had a higher level of satisfaction with police although this can be attributed somewhat to our sample which is skewed older). 
Sir Robert Peel declared that " $[\mathrm{t}]$ he ability of the police to perform their duties is dependent upon public approval of police actions." There exists significant scope and opportunity in Victoria for improvements to policing practice to allow generate enhanced satisfaction with police and thus more effective crime prevention and control.

To conclude: a call to arms! Whilst the body or research on farm victimisation is growing internationally, missing from the canon of scholarship in this field is comparative data. How do the attitudes of farmers in, say, Victoria, Australia compare with those in other jurisdictions? What are the points of comparison and the points of difference? A number of colleagues are currently working on adapting the survey instrument to deploy in place such as New South Wales in Australia, Sweden, Brazil, South Africa and France. Any rural scholars with an interest in participating in such an international comparative project are invited to contact the lead author of this article.

\section{Endnotes}

${ }^{1}$ Image sourced from ABARES (2018).

${ }^{2}$ The authors acknowledge the efforts of Melina Stewart-North and Kerry De Vent, who both provided research assistance including data collection, data entry and statistical analysis.

${ }^{3}$ Victoria's Agricultural Liaison Officers (AGLOs) were renamed as Farm Crime Liaison Officers (FCLOs) on 23 September 2019. The survey asked respondents about their perceptions of AGLOs and so they will be referred to as such in the results presented here.

\section{References}

ABARES. (2018). About my region - Victoria. Canberra, ACT: Department of Agriculture and Water Resources. Retrieved 1/11/2018 from

http://www.agriculture.gov.au/abares/research-topics/aboutmyregion/vic\#regionaloverview

ABS. (2017). Regional population by age and sex, Australia, 2017. Cat. No. 3235.0.

Canberra, ACT: Australian Bureau of Statistics. Retrieved 30/4/2019 from http://www.abs.gov.au/ausstats/abs@.nsf/Latestproducts/3235.0Main\%20Features320 17 opendocument\&tabname $=$ Summary \&prodno $=3235.0 \&$ issue $=2017 \&$ num $=\& v i e w$

ABS. (2018). Quickstats for Census 2016. Canberra, ACT: Australian Bureau of Statistics. Retrieved 1/11/2018 from https://quickstats.censusdata.abs.gov.au/census_services/getproduct/census/2016/quic kstat/2?opendocument

Agriculture Victoria. (2018). Agriculture in Victoria. Melbourne, Vic: Department of Economic Development, Jobs, Transport and Resources. Retrieved 1/11/2018 from http://agriculture.vic.gov.au/agriculture\#

Anderson, K.M. and McCall, M. (2005). Farm crime in Australia. Canberra, ACT: Australian Government Attorney-General's Department. 
Baker, D. (2005). Batons and blockades: Policing industrial disputes in Australasia. Beaconsfield, Vic: Circa.

Baker, D. (2014). Police, picket-lines and fatalities: Lessons from the past. Basingstoke, UK: Palgrave McMillan. https://doi.org/10.1057/9781137358066

Baker, D. (2016). Policing of protest in rural and regional contexts. In A. Harkness, B. Harris and D. Baker (Eds.). Locating crime in context and place: Perspectives on regional, rural and remote Australia (pp. 85-95). Sydney, NSW: The Federation Press.

Barclay, E, Donnermeyer, J.F., Doyle, B and Talary, D. (2001). Property crime victimisation and crime prevention on farms. Report to the NSW Attorney-General's Crime Prevention Division. Armidale, NSW: Institute for Rural Futures, University of New England.

Barclay, E. (2003). The determinants of reporting farm crime in Australia. International Journal of Comparative and Applied Criminal Justice, 27(2), 131-151. https://doi.org/10.1080/01924036.2003.9678706

Barclay, E. (2015). Crime on farms: A survey of farmers in NSW and Queensland 20012014. Final report to NSW and Queensland Police (unpublished). Armidale, NSW: University of New England.

Barclay, E. (2016). Farm victimisation: The quintessential rural crime. In J.F. Donnermeyer (Ed.). The Routledge international handbook of rural criminology (pp. 107-116). London, UK: Routledge. https://doi.org/10.4324/9781315755885-13

Barclay, E. and Donnermeyer, J. (2007). Farm victimisation: The quintessential rural crime. In E. Barclay, J.F. Donnermeyer, J. Scott and R. Hogg (Eds.), Crime in rural Australia (pp, 57-68). Sydney, NSW: The Federation Press.

Barclay, E., Donnermeyer, J.F., Scott, J. and Hogg, R. (Eds.). (2007). Crime in rural Australia. Sydney, NSW: The Federation Press.

Bradford, B., Jackson, J, and Stanko, E.A. (2009). Contact and confidence: Revisiting the impact of public encounters with the police. Policing and Society, 19(1), 20-46. https://doi.org/10.1080/10439460802457594

Bristow, A.P. (1982). Rural law enforcement. Needham Heights, MA: Allyn and Bacon.

Buttle. J., Fowler, C. and Williams, M.W. (2010). The impact of rural policing on the private lives of New Zealand police officers. International Journal of Police Science and Management, 12(4), 596-606. https://doi.org/10.1350/ijps.2010.12.4.202

Carcach, C. (2002). Farm victimisation in Australia. Trends and issues in crime and criminal justice, 235. Canberra. ACT: Australian Institute of Criminology.

Carcach, C. (2000). Size, accessibility and crime in regional Australia. Trends and issues in crime and criminal justice, 175. Canberra, ACT: Australian Institute of Criminology.

Ceccato, V. (2016). Rural crime and community safety. London, UK: Routledge. https://doi.org/10.4324/9780203725689 
Farmer satisfaction with policing in rural Victoria, Australia - Harkness and Larkins

Clack, W. (2013). The extent of stock theft in South Africa. Acta Criminologica: Southern African Journal of Criminology, 26(2), 79-91.

Clack, W. and Minnaar, A. (2018). Rural crime in South Africa: An exploratory review of 'farm attacks' and stock theft as the primary crimes in rural areas. Acta Criminologica: Southern African Journal of Criminology, 31(1), 104-136

Donnermeyer, J.F. (2007). Rural crime: Roots and restoration. International Journal of Rural Crime, 1, 2-20.

Donnermeyer, J.F. (2016). Introduction. In J.F. Donnermeyer (Ed.) The Routledge international handbook of rural criminology. London, UK: Routledge. https://doi.org/10.4324/9781315755885

Donnermeyer, J.F. (1995). Crime and violence in rural communities. Midwest Regional Center for Drug-Free Schools and Communities, North Central Regional Educational Laboratory.

Donnermeyer, J.F. and Barclay, E. (2005). The policing of farm crime. Police Practice andResearch, 6(1), 3-17. https://doi.org/10.1080/15614260500046913

Donnermeyer, J.F., Jobes, P. and Barclay E. (2006). Rural crime, poverty and community. In W.S. DeKeseredy and B. Perry (Eds.). Advancing critical criminology. Lanham, MA: Lexington Books.

Goldsmith, A. (2005). Police reform and the problem of trust. Theoretical Criminology, 9(4), 443-470. https://doi.org/10.1177/1362480605057727

Haldane, R. (1995). The people's force: A history of Victoria Police (2nd edn). Carlton, Vic: Melbourne University Press.

Harkness, A. (2015, July). Policing strategies to farm crime: Lessons from Victoria. Crime Justice and Social Democracy Conference proceedings. Brisbane, Qld: Queensland University of Technology.

Harkness, A. (2016). Farm crime: The forgotten frontier. In A. Harkness, B. Harris and D. Baker (Eds), Locating crime in context and place: Rural and regional perspectives (pp. 96-107). Sydney, NSW: The Federation Press.

Harkness, A. (2018, 2 May). Rural crime: Under-reporting thefts from farmers creates vicious cycle. The Weekly Times. Retrieved 4 May 2019 from

https://www.weeklytimesnow.com.au/news/opinion/rural-crime-underreportingthefts-from-farmers-creates-vicious-cycle/newsstory/28ac242daf7dcf190a20ec3884106704

Harkness, A. (2017). Crime prevention on farms: Experiences from Victoria, Australia. International Journal of Rural Criminology, 3(2), 131-156. https://doi.org/10.18061/1811/81050

Harkness, A., Harris, B. and Baker, D. (Eds.). (2016). Locating crime in context and place: Perspectives on regional, rural and remote Australia. Sydney, NSW: The Federation Press. 
Harris, B. and Harkness A. (2016). Introduction: Locating regional, rural and remote crime in theoretical and contemporary context. In A. Harkness, B. Harris and D. Baker (Eds.), Locating crime in context and place: Perspectives on regional, rural and remote Australia (pp. 1-12). Sydney, NSW: The Federation Press.

Hogg, R. and Carrington, K. (2006). Policing the rural crisis. Sydney, NSW: The Federation Press.

Holmes, M.D, Painter II, M.A. and Smith, B.W. (2017). Citizens' perceptions of police in rural US communities: A multilevel analysis of contextual, organisational and individual predictors. Policing and Society, 27(2), 136-156. https://doi.org/10.1080/10439463.2015.1031227

Jackson, J. and Bradford, B. (2010). What is trust and confidence in the police? Policing: A Journal of Policy and Practice, 4(3). 241-248. https://doi.org/10.1093/police/paq020

Jobes, P. (2003). HUMAN ecology and rural policing: A grounded theoretical analysis of how personal constraints and community characteristics influence strategies of law enforcement in rural New South Wales, Australia. Police Practice and Research: An International Journal, 4(1), 3-19. https://doi.org/10.1080/1561426032000059150

Jobes, P.C. (2002). Effective officer and good neighbour: Problems and perceptions among police in rural Australia. Policing: An International Journal of Police Strategies and Management, 25(2), 256-273. https://doi.org/10.1108/13639510210429365

Jobes, P.C., Barclay, E. and Donnermeyer, J.F. (2000). A qualitative and quantitative analysis of the relationship between community cohesiveness and rural crime, Part 2. Armidale, NSW: The Institute for Rural Futures, University of New England.

Jones, J. (2010). The neglected problem of farm crime: An exploratory study. Safer Communities, 9(1), 36-44. https://doi.org/10.5042/sc.2010.0013

Laird, A, Granville, S. and Montgomery, R. (1999). Crime and the farming community: The Scottish Farm Crime Survey 1998. Edinburgh, UK: The Scottish Office Central Research Unit.

Marenin, O. and Copus, G. (1991). Policing rural Alaska: The Village Public Safety Officer (VPSO) Program. American Journal of Police, 10(4), 1-26.

Mawby, R.I. (2004). Myth and reality in rural policing: Perceptions of the police in a rural county of England. Policing, 27(3), 431-446. https://doi.org/10.1108/13639510410553158

Mawby, R.I. and Yarwood, R. (Eds.) (2016). Rural policing and policing the rural: A Constable Countryside?, London, UK: Routledge. https://doi.org/10.4324/9781315607191

McCall, M. and Homel, P. (2003). Preventing crime on Australian farms: Issues, current initiatives and future directions. Trends and Issues in Crime and Criminal Justice, 268. Canberra, ACT: Australian Institute of Criminology. 
Muhammad, B.R. (2002). Rural crime and rural policing practices (multicultural law enforcement). Applied research project submitted to the Department of Interdisciplinary Technology as part of the School of Police Staff and Command Program, Detroit Police Department. Retrieved 24/04/2019 from http://citeseerx.ist.psu.edu/viewdoc/download?doi=10.1.1.594.4468\&rep=rep1\&type= pdf

National Rural Crime Network. (2018). Living on the edge: Why crime and anti-social behaviour is leaving rural communities and businesses frustrated, undervalued and isolated. Report and Recommendations from the 2018 National Rural Crime Survey. Harrogate, UK: National Rural Crime Network.

NSW Police. (2019). Rural. Sydney, NSW: New South Wales Police. Retrieved 3/5/2019 from https://www.police.nsw.gov.au/safety_and_prevention/safe_and_secure/rural_crime

O’Connor, M. and Gray, D. (1989). Crime in a rural community. Sydney, NSW: The Federation Press.

Peel, Sir Robert. (1829). Sanctions of Establishment of Police. No 8 Augmentation. London: Home Office.

Public Records Office Victoria. (2016). Police. North Melbourne: Public Records Office Victoria. Retrieved 30/11/2018 from http://www.access.prov.vic.gov.au/public/component/daPublicBaseContainer?compo nent $=$ daViewFunction\&breadcrumbPath $=$ Home/Access $\% 20$ the $\% 20$ Collection/Brows e\%20The\%20Collection/Function\%20Details\&entityId=10 (accessed 5 November 2018)

Scott, J. and Jobes, P.C. (2007). Policing in rural Australia: The country cop as law enforcer and local resident. In E. Barclay, J.F. Donnermeyer, J. Scott and R. Hogg (Eds.), Crime in rural Australia. Sydney, NSW: The Federation Press.

Scott, J., Hogg, R., Barclay, E. and Donnermeyer, J.F. (2007). Introduction. In Barclay, E., Donnermeyer, J.F., Scott, J. and Hogg, R. (Eds). Crime in rural Australia (pp. 1-12). Sydney, NSW: The Federation Press.

Sims, V.H. (1988). Small town and rural police. Springfield, IL: Charles C. Thomas.

Victoria Police. (2019). Victoria Police employees by location at March 2019. Melbourne: Victoria Police. Retrieved 3/5/2019 from https://content.police.vic.gov.au/sites/default/files/201904/Victoria\%20Police\%20Employee\%20numbers\%20Mar\%202019.pdf?_ga=2.1035 06949.486127273.1556850612-2116368120.1556240338

Weisheit, R.A. and Wells, L.E. (1996). Rural crime and justice: Implications for theory and research. Crime and Delinquency, 42(3), 379-397. https://doi.org/10.1177/0011128796042003003

Weisheit, R.A., Falcone, D.N. and Wells, K.L.E. (1999). Crime and policing in rural and small-town America (2nd edn). Long Grove, CA: Waveland Press. 
International Journal of Rural Criminology, Volume 5, Issue 1 (November), 2019

Weisheit, R.A., Falcone, D.N. and Wells, K.L.E. (2006). Crime and Policing in rural and small-town America (3rd edn). Long Grove, CA: Waveland Press.

Weisheit, R.A., Falcone, D.N. and Wells, L.E. (1994). Rural crime and rural policing. Rockville, MD: National Institute of Justice, US Department of Justice Office of Justice Programs, September.

Wooff, A. (2016). 'Soft' policing in rural Scotland. Policing: A Journal of Policy and Practice, 11(2), 123-131. https://doi.org/10.1093/police/paw031 